Article

\title{
Synthesis of vitamin E succinate by interfacial activated Candida rugosa lipase encapsulated in sol-gel materials
}

\author{
Yi Hu a,b, Xiangjun Jiang a, Suwen $\mathrm{Wu}^{\mathrm{a}}$, Ling Jiang a,b, He Huang a,b,* \\ ${ }^{a}$ College of Biotechnology and Pharmaceutical Engineering, Nanjing University of Technology, Nanjing 210009, Jiangsu, China \\ b State Key Laboratory of Materials-Oriented Chemical Engineering, Nanjing University of Technology, Nanjing 210009, Jiangsu, China
}

A R T I C L E I N F 0

Article history:

Received 22 April 2013

Accepted 28 May 2013

Published 20 August 2013

\section{Keywords:}

Sol-gel

Interfacial activation

Candida rugosa lipase

Vitamin E succinate

\begin{abstract}
A B S T R A C T
Vitamin E succinate was synthesized by interfacial activated Candida rugosa lipase (CRL) encapsulated in sol-gel materials. The effects of various immobilization parameters were investigated. The optimum conditions were found to consist of $n$-propyltrimethoxysilane/tetraethoxysilane molar ratio $=1 / 1$, water $/$ silane molar ratio $(R$ value $)=20$, lipase loading $=0.5 \mathrm{mg} / \mathrm{ml} \mathrm{sol}$, and PEG400 loading $=12 \mu \mathrm{l} / \mathrm{ml}$ sol. Compared with free enzymes, sol-gel encapsulated enzymes kept its activity of $70.58 \%$ and achieved 2.6 -fold increased stability after $18 \mathrm{~h}$ incubation in phosphate buffer $(0.025$ $\mathrm{mol} / \mathrm{L}, \mathrm{pH}=7.0$ ) at $50{ }^{\circ} \mathrm{C}$. Based on the interfacial characteristics of CRL, five kinds of surfactants were used for activation. The results demonstrate that olive oil was the most effective in activating CRL. The esterification activity of vitamin E succinate synthesis by interfacial activated CRL encapsulated in sol-gel materials reached up to 6.7-fold and 1.43-fold that of free enzyme and non-interfacial activated enzyme, respectively.
\end{abstract}

(C) 2013, Dalian Institute of Chemical Physics, Chinese Academy of Sciences. Published by Elsevier B.V. All rights reserved.

\section{Introduction}

Immobilized enzymes have been used in a wide number of applications due to advantages of high stability, separation, recyclability, easy transport and storage, and continuous and automatic production [1,2]. Entrapping the enzyme in sol-gel formed by organic silane precursors further enhances its thermal stability and resistance to organic solvents, high enzymic activity, and maintains the advanced structure of the enzyme. This is an important immobilization method [3,4]. Nguyen et al. [5] reported that creatine kinase entrapped in sol-gel was obtained using tetramethyl orthosilicate as silane precursors. The results demonstrate that the thermal stability of the immobilized enzyme was greatly improved. At $60{ }^{\circ} \mathrm{C}$ the immobilized enzyme retained $50 \%$ of its maximum activity after $5 \mathrm{~h}$ incuba- tion. Noureddini et al. [6] reported that lipase AY was entrapped in sol-gel formed using isobutyltrimethoxysilane and tetramethyl orthosilicate as silane precursors. The immobilized lipase was stable up to $70^{\circ} \mathrm{C}$, whereas for the free enzyme, a moderate to severe loss of activity was observed beyond $40{ }^{\circ} \mathrm{C}$. The immobilized lipase also retained more than $95 \%$ of its initial activity after twelve reactions.

The thermal stability of the enzyme could be enhanced by the sol-gel encapsulating immobilization method. However, the catalytic efficiency of the entrapped enzyme was also low, mainly because entrapped enzyme did not have a suitable conformation to form the product. Most lipases have a lid-like structure. The substrates enter the catalytic center of lipases and the catalytic behavior is fulfilled after the "lid" of the enzyme opens. Maruyama et al. [7] demonstrated that the lid of

\footnotetext{
*Corresponding author. Tel/Fax: +86-25-83172094; E-mail: biotech@njut.edu.cn

This work was supported by the National Science Foundation for Distinguished Young Scholars of China (21225626), the National Natural Science Foundation of China (20906049), and the High Technology Research and Development Program of China (863 Program, 2011AA02A209). DOI: 10.1016/S1872-2067(12)60628-7 | http://www.sciencedirect.com/science/journal/18722067| Chin. J. Catal., Vol. 34, No. 8, August 2013
} 
most enzymes was closed in the water phase but would open at the oil-water interface. Interface activation was not available for the organic solvents, as they cause the lid of the lipase to close and results in low catalytic efficiency. If the lid of the lipase could be opened before catalytic behavior, the catalytic efficiency could be greatly improved. Generally speaking, the lipase lid could be opened by interfacial activation formed at the oil-water phase. Foresti et al. [8] reported that Candida rugosa lipase (CRL) adsorbed on polypropylene powder was subjected to interfacial activation in order to enhance ethyl oleate synthesis activity in solvent-free. The esterification activity was increased by up to $29 \%$ compared with non-interfacial activated enzyme. Yilmaz [9] employed surfactants such as lecithin, Tween 20, and olive oil to activate porcine pancreatic lipase and Pseudomonas fluorescens liapse. The results show that the interesterification activities of both porcine pancreatic lipase and Pseudomonas fluorescens lipase were quadrupled by lecithin.

Vitamin E succinate is one of the important vitamin E derivatives. It has remarkable effects against all kinds of tumors, including colon and breast tumors. In particular, it has no influence on the proliferation of normal cells, making it a potential anti-cancer drug $[10,11]$. Recently, to ensure environmentally friendly processing, synthesis by enzyme-catalyzed reactions instead of traditional chemical catalysts has become of commercial interest $[12,13]$. Biocatalysts have been widely used in many kinds of reactions. For example, the Michael addition reaction, Markovnikov addition reaction, and aldol condensation use biocatalysts $[14,15]$. Torres et al. [16] described the enzymatic acylation of vitamin $E$ with vinyl acetate in 2-methyl-2-butanol for the first time, in which Novozym 435 was chosen as the catalyst, reaching a yield of about $65 \%$ after 18 days. Yin et al. [17] described the synthesis of vitamin E succinate using a chemically modified Novozym 435 in tert-butanol and DMSO ( $/ \mathrm{v}=2: 3)$. The yield of vitamin $\mathrm{E}$ succinate reached $94.4 \%$ after $48 \mathrm{~h}$, while the yield was only $13.13 \%$ with unmodified Novozym 435 . In this study, sol-gel encapsulating immobilization and interfacial activation were employed to improve the esterification activity of CRL in the synthesis of vitamin E succinate (Scheme 1). This research also

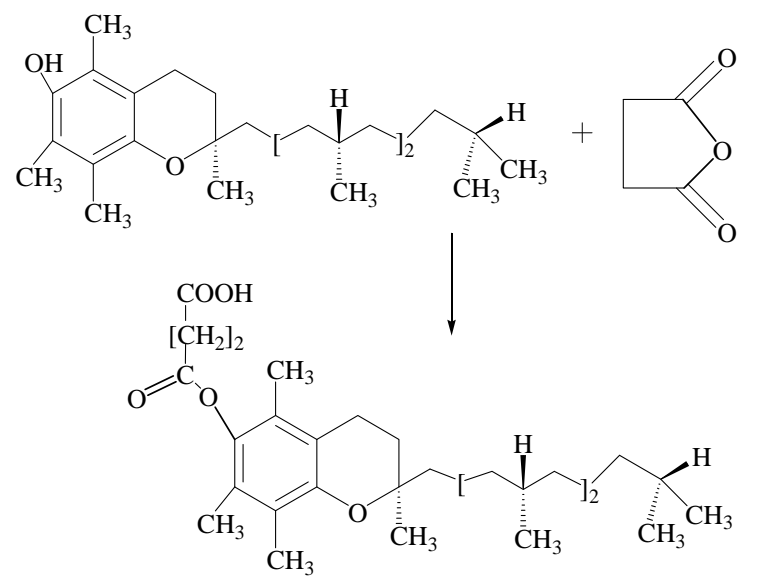

Scheme 1. Synthesis pathway of vitamin E succinate by interfacial activated Candida rugosa lipase (CRL) encapsulated in sol-gel materials. explored the influence of different kinds of enzymes and organic solvents, as well as the operating conditions on the synthesis of vitamin E succinate [18].

\section{Experimental}

\subsection{Preparation for CRL encapsulated in sol-gel materials}

A certain amount of CRL (Sigma-Aldrich) was first dissolved in phosphate buffer $(0.025 \mathrm{~mol} / \mathrm{L}, \mathrm{pH}=7.0)$ and centrifuged (6000 r/min, $4{ }^{\circ} \mathrm{C}, 10 \mathrm{~min}$ ) to remove any insoluble material. The supernatant was obtained. A mixture of $n$-propyltrimethoxysilane (PTMS, 97\%, Aladdin-reagent)/tetraethoxysilane (TEOS, AR, Aladdin-reagent, $12 \mathrm{mmol}$ ), $1.5 \mathrm{ml}$ deionized water, $\mathrm{HCl}$ solution $(1 \mathrm{~mol} / \mathrm{L}, 90 \mu \mathrm{l})$, and a certain amount of polyethylene glycol 400 (PEG400, Sinopharm Chemical Reagent Co. Ltd.) were intensively agitated at $0{ }^{\circ} \mathrm{C}$ for $30 \mathrm{~min}$. The supernatant was added to the above hydrolyzed silane solution. The mixture was vigorously agitated for $10 \mathrm{~min}$ and then at $100 \mathrm{r} / \mathrm{min}$ for another $1 \mathrm{~h}$. The agitated mixture was aged at 4 ${ }^{\circ} \mathrm{C}$ for $24 \mathrm{~h}$, then dried in air at $30^{\circ} \mathrm{C}$ for $3 \mathrm{~d}$. Finally, the generated gel was crushed and the immobilized enzyme was obtained.

\subsection{Preparation for interfacial activated CRL encapsulated in sol-gel materials}

A certain amount of lipase powder was dissolved in phosphate buffer $(0.025 \mathrm{~mol} / \mathrm{L}, \mathrm{pH}=7.0)$ and centrifuged $(6000$ $\mathrm{r} / \mathrm{min}, 4{ }^{\circ} \mathrm{C}, 10 \mathrm{~min}$ ) to remove any insolubles. The supernatant was obtained. A certain amount of olive oil, triacetin, Tween 20 , lecithin, and $n$-octyl glucoside ( $n$-OG, Sinopharm Chemical Reagent Co. Ltd.) was added into the supernatant. Sol-gel immobilization was performed as described in Section 2.1. Interfacial activated CRL encapsulated in sol-gel material was dried and crushed. n-OG and Tween 20 were washed with benzene/ethanol (90/10). Olive oil, triacetin, and lecithin were washed with $n$-hexane. The interfacial activated CRL encapsulated in sol-gel materials was then dried in air.

\subsection{Immobilization efficiency assay}

The dried sol-gel was washed by a phosphate buffer and the washed buffer collected. Protein was determined according to Bradford's method using bovine serum albumin (Aladdin-reagent) as a standard [19]. The immobilization efficiency (IY) was calculated from the formula: $\mathrm{IY}=\left(C_{\mathrm{i}}-C_{\mathrm{f}} / C_{\mathrm{i}}\right) \times 100 \%$, where $C_{\mathrm{i}}$ and $C_{\mathrm{f}}$ mean the concentration of the initial and final enzyme protein concentrations in the immobilization medium $(\mathrm{mg} / \mathrm{ml})$.

\subsection{Specific surface area and pore diameter assays}

$\mathrm{N}_{2}$ adsorption-desorption assays of silane particles were conducted on a Micromeritics ASAP 2020 analyzer. All the samples were degassed at $80{ }^{\circ} \mathrm{C}$ for $12 \mathrm{~h}$ before measurement. Specific surface area was determined by BET model, and the 
pore diameter was determined by BJH method [18].

\subsection{Hydrolysis activity assays}

The hydrolysis activity of enzyme was determined by olive oil hydrolysis. A mixture of $8.5 \mathrm{~g}$ of gum arabic powder (Sinopharm Chemical Reagent Co. Ltd), $100 \mathrm{ml}$ of deionized water, and $100 \mathrm{ml}$ of olive oil (AR, Sinopharm Chemical Reagent Co. Ltd) was stirred overnight at room temperature to prepare the olive oil emulsion. The enzyme solution consisted of $10 \mathrm{ml}$ phosphate buffer $(0.025 \mathrm{~mol} / \mathrm{L}, \mathrm{pH}=7.0), 10 \mathrm{ml}$ olive oil emulsion and a certain amount of enzyme. The mixture was continuously titrated with $0.025 \mathrm{~mol} / \mathrm{L} \mathrm{NaOH}$ to maintain the $\mathrm{pH}$ at 7.0. The hydrolysis temperature was strictly controlled at 35 ${ }^{\circ} \mathrm{C}$. The volume of $\mathrm{NaOH}$ consumed in $10 \mathrm{~min}$ was recorded. Hydrolysis activity (U) was determined by calculating the consumption of $\mathrm{NaOH}$ and was defined as micromoles per minute per gram of protein.

\subsection{Thermal stability assays}

A certain amount of enzyme was dissolved in phosphate buffer $(0.025 \mathrm{~mol} / \mathrm{L}, \mathrm{pH}=7.0)$ at $30-60{ }^{\circ} \mathrm{C}$ for $18 \mathrm{~h}$. The enzyme solution was then cooled and added into the olive oil system. The hydrolysis activity was measured as 2.5 .

\subsection{Esterification activity assays}

Enzymatic esterification was typically performed in a reaction mixture consisting of $1 \mathrm{mmol}$ vitamin E (AR, Sinopharm Chemical Reagent Co. Ltd), $5 \mathrm{mmol}$ succinic anhydride (AR, Sinopharm Chemical Reagent Co. Ltd), a certain amount of free enzyme, enzyme encapsulated in sol-gel material, or interfacial activated enzyme encapsulated in sol-gel material, and $5 \mathrm{ml}$ DMSO (AR, Sinopharm Chemical Reagent Co. Ltd). The reaction was performed in tightly closed $25 \mathrm{ml}$ conical flasks, in a water bath of $55{ }^{\circ} \mathrm{C}$, agitated with mechanical stirring at $150 \mathrm{r} / \mathrm{min}$ and a reaction time of $18 \mathrm{~h}$. Quantitative analysis of the reactants and products were conducted by HPLC system from Shimadzu, Japan. A reversed-phase column (Sepax BR-C18, 250 $\mathrm{mm} \times 4 \mathrm{~mm}, 5 \mu \mathrm{m}$ ) was used and the reactants and products detected by SPD-20AVP UV-Vis detector at $285 \mathrm{~nm}$. A mixture of methanol/acetic acid, 50/0.3 (v/v), was used as an eluent at $36{ }^{\circ} \mathrm{C}$ with a flow rate of $1 \mathrm{ml} / \mathrm{min}$. Esterification activity was determined by calculating the transformation of the substrate (vitamin E) to ester, and was defined as micromoles per hour per gram of protein.

\section{Results and discussion}

\subsection{Effects of immobilization conditions on the immobilized $C R L$}

\subsubsection{Effect of molar ratio of silane precursors}

The molar ratio of the hydrophobic and hydrophilic silane precursors determines the hydrophobicity of the gel. When the ratio is higher, the hydrophobicity of the growing gel results in

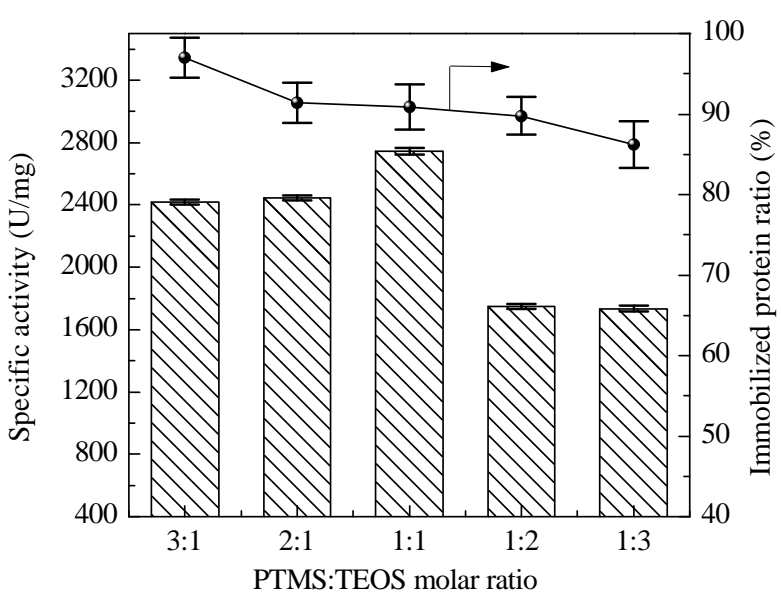

Fig. 1. Effect of the PTMS to TEOS molar ratio on the specific activity and immobilized protein ratio of immobilized enzymes.

microscopic phase separation, during which the aqueous phase solution might be squeezed out of the gel phase. Hence, when the phase separation and the gelation proceeded at a certain balanced rate, some lipase molecules could be aptly trapped near the surface of the resulting gel [20]. As lipases are interface active enzymes, a suitable surface hydrophobicity of the gel might be helpful to maintain favorable molecular conformation and hence enhance activity [3]. So an optimum molar ratio of the hydrophobic and hydrophilic silane precursors is desirable. The effect of the molar ratios of hydrophobic PTMS and hydrophilic TEOS on the specific activity and immobilized protein ratio of the immobilized enzymes were investigated and the results are shown in Fig. 1. When the amount of PTMS decreased in the precursor mixture, the immobilization protein ratio fell, while the specific activity first enhanced and then decreased, achieving a maximum value at the molar ratio of $1 / 1$. Therefore, $1 / 1$ was selected as the optimum silane precursor molar ratio for further experiments.

\subsubsection{Effect of lipase loading}

Lipase loading directly influences the support loading and indirectly influences the specific activity of immobilized enzymes. Enzyme denaturation by the hydrophobic gel material with low lipase loading might explain the initial activity increase [21]. Intraparticle diffusion limitations and/or enzyme aggregation may be responsible for decreased activity at high enzyme loading. When the PTMS/TEOS molar ratio was $1: 1$, the water/silane precursor molar ratio ( $R$ value) was 20 , and the amount of PEG was $80 \mu \mathrm{l} / \mathrm{ml}$ sol, the effect of varied lipase loading on immobilization was investigated and the results are shown in Fig. 2. The specific activity and immobilized protein ratio increased with increasing enzyme loading when the lipase loading was less than $0.5 \mathrm{mg} / \mathrm{ml}$. The specific activity and immobilized protein ratio decreased with increasing enzyme loading when the lipase loading was above $0.5 \mathrm{mg} / \mathrm{ml}$. When the lipase loading was $0.5 \mathrm{mg} / \mathrm{ml}$, the highest values of specific activity and immobilized protein ratio were achieved.

\subsubsection{Effect of the molar ratio of water to silane precursor}




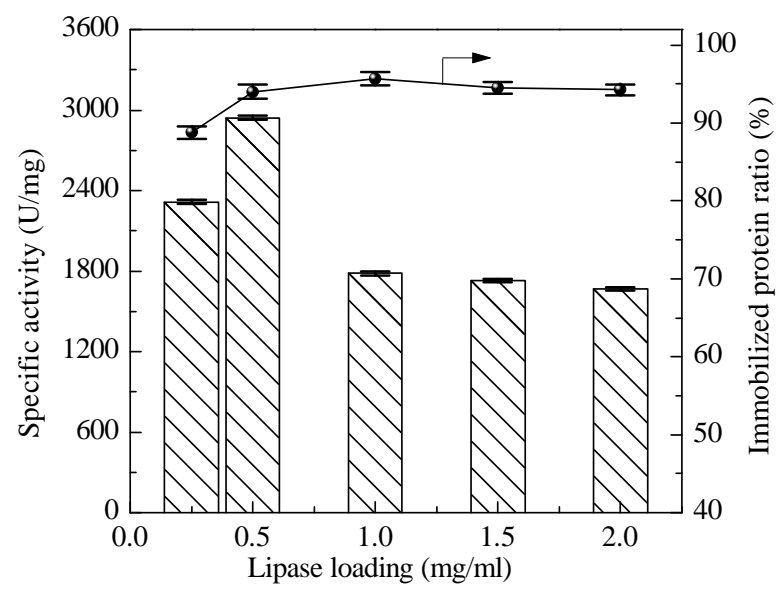

Fig. 2. Effect of lipase loading on specific activity and immobilized protein ratio of immobilized enzymes.

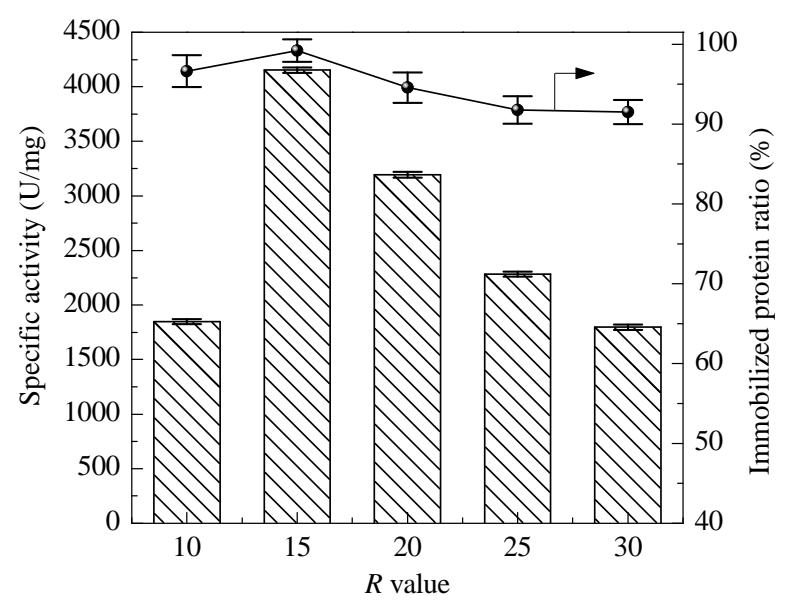

Fig. 3. Effect of the R values on specific activity and immobilized protein ratio of immobilized enzymes.

The molar ratio of total water to silane precursor was usually reflected by the $R$ value in the gel-forming reaction. As shown in Fig. 3, the specific activity and immobilized protein ratio were low when the $R$ values $<15$. The specific activity and immobilized protein ratio decreased when the $R$ values $>15$. Both the specific activity and immobilized protein ratio achieved the highest values when the $R$ value $=15$. Lower $R$ values might result in enzyme aggregation, which leads to low activity. Alcohol condensation was also likely to occur during network forming and might damage the enzymes. However, at higher $R$ values, more lipase molecules remained in the aqueous supernatant, so a lower immobilized protein ratio resulted [22].

\subsubsection{Effect of PEG400 amount}

PEG400 adsorbed onto the surface of the gel before the enzyme, which weakened interactions between the enzyme and gel. PEG400 was able to maintain enzyme activities because of their satisfactory biocompatibility. The amount of PEG400 had a significant influence on the gel structure $[23,24]$.

As shown in Fig. 4, when the amount of PEG400 increased, the specific activity was first raised and then declined, with a

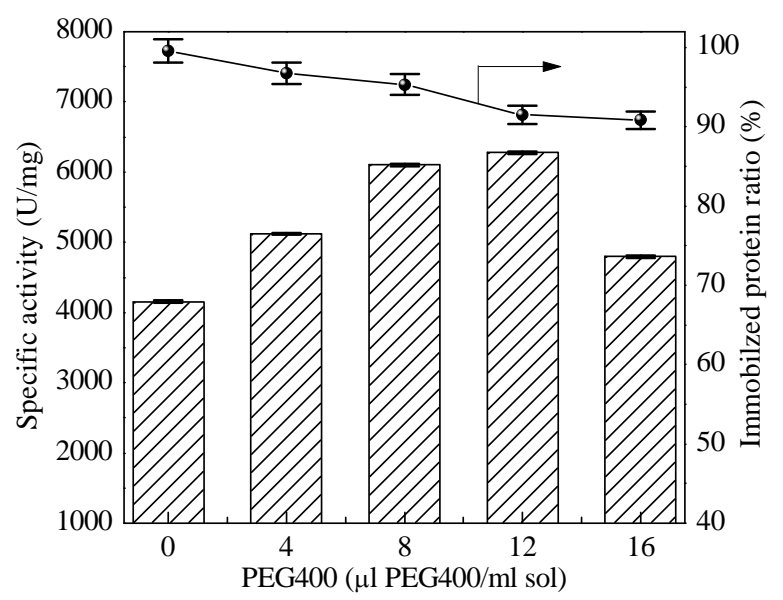

Fig. 4. Effect of PEG on the specific activity and immobilized protein ratio of immobilized enzyme.

maximum value $(6279.12 \mathrm{U} / \mathrm{mg})$ at the point of $12 \mu \mathrm{l} / \mathrm{ml}$. The specific activity improved by 3.6 times that of free enzymes. The immobilized protein ratio reached $95.3 \%$. The optimum immobilized conditions of PTMS $/$ TEOS $=1 / 1(\mathrm{~mol} / \mathrm{mol})$, water $/$ silane molar ratio $(R$ value $)=20$, lipase loading $=0.5$ $\mathrm{mg} / \mathrm{ml}$ sol, and PEG400 loading $=12 \mu \mathrm{l} / \mathrm{ml}$ sol were found by exploring the immobilized conditions.

\subsubsection{Specific surface area and pore diameter of the gels}

The specific surface area and pore diameter of the gels were also determined by $\mathrm{N}_{2}$ adsorption-desorption assays. As shown in Table 1, compared with the blank gels, the specific surface area of the immobilized enzymes increased, while the pore diameter of the immobilized enzymes decreased. Enzyme molecules were encapsulated in the sol-gel material in the gel-forming reaction. The structure of the gels was loose and porous, which resulted in high specific surface area. The pore diameter of the gels decreased because enzyme was encapsulated in sol-gel materials. These changes demonstrated that the enzyme was successfully encapsulated in the sol-gel materials. The specific surface area of the immobilized enzymes was also bigger than that of the blank gels, which favors movement of the substrates and products coming in and out of the enzyme catalytic active center. This results in high enzyme catalytic efficiency $[25,26]$.

\subsection{Enzymatic properties}

\subsubsection{Thermal stability}

Thermal stability is an important character of enzymes. Nguyen et al. [5] reported that enzymes by sol-gel encapsulation obtain higher stability. The thermal stability of the lipase encapsulated by PTMS/TEOS was investigated at the immobi-

Table 1

BET surface area and average pore width.

\begin{tabular}{lcc}
\hline Sample & $\begin{array}{c}\text { BET surface area } \\
\left(\mathrm{m}^{2} / \mathrm{g}\right)\end{array}$ & $\begin{array}{c}\text { Average pore width } \\
(\mathrm{nm})\end{array}$ \\
\hline Blank & 43.23 & 4.23 \\
Immobilized enzyme & 54.71 & 3.26 \\
\hline
\end{tabular}




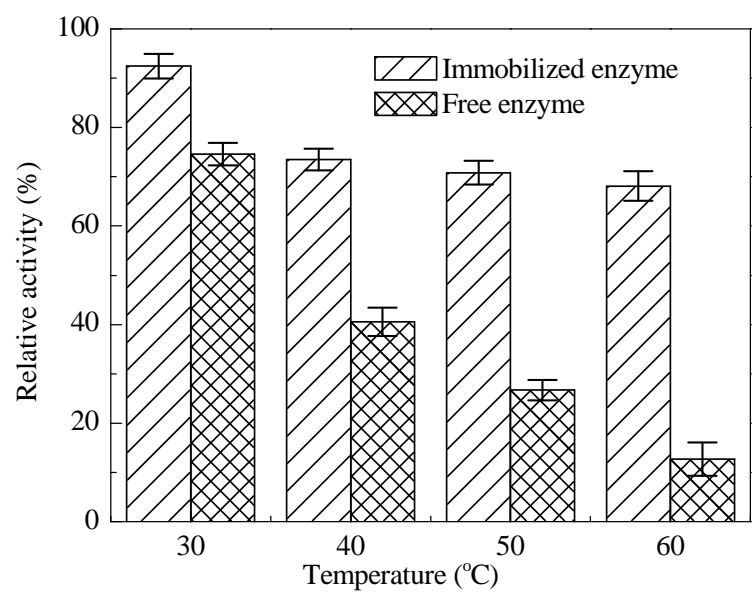

Fig. 5. Thermal stability of free and immobilized enzyme.

lization conditions described above. It was shown in Fig. 5 that the improved thermal resistance was achieved after immobilization. Especially at high temperatures of 50 and $60{ }^{\circ} \mathrm{C}$, the immobilized enzyme kept $70.58 \%$ and $68.11 \%$ of its enzymatic activity, while the free enzyme kept $26.72 \%$ and $12.68 \%$, respectively. The enhanced stability of the sol-gel encapsulated enzymes might be attributed to the global movement (e.g. unfolding, rotating) being restricted by the rigid polymer [24].

\subsubsection{Comparison of esterification activity of CRL by interfacial activation with different surfactants}

The difference between lipase and other esterase lies in the performance of the lipase-catalytic behavior at the oil-water interface, which was determined by the unique "lid" structure. The crystallography of the lipase demonstrated that there was a helicoid lid covering the catalytic triad of the lipase, which separated the catalytic center from the surface of lipase. There was an electrophilic area (oxygen anion hole) formed by the hydrophobic and hydrophilic groups under the lid [25]. The lid was open and the catalytic center was exposed to the water-organic interface. Therefore, the substrates could easily combine in the catalytic center. From the data presented in Table 2, it was demonstrated that the esterification activity of the interfacial activated immobilized lipase improved by varying degrees compared with free and immobilized lipase. Among the surfactants tested, the best surfactant was olive oil and the esterification activity of the interfacial activated lipase encapsulated in sol-gel materials was $7.59 \times 10^{4} \mathrm{U}$. The esterification activity of the free enzyme was $1.13 \times 10^{4} \mathrm{U}$. The esterification activity of vitamin $\mathrm{E}$ succinate synthesis by interfacial activated

\section{Table 2}

Esterification activity of encapsulated CRL by interfacial activation with different surfactants for the synthesis of vitamin E succinate.

\begin{tabular}{lcc}
\hline Surfactant & Esterification activity (U) & Change \\
\hline Blank & $5.31 \times 10^{4}$ & 1 \\
Triacetin & $5.98 \times 10^{4}$ & 1.13 \\
Lecithin & $6.25 \times 10^{4}$ & 1.17 \\
Tween 20 & $6.65 \times 10^{4}$ & 1.25 \\
$n$-OG & $6.77 \times 10^{4}$ & 1.27 \\
Olive oil & $7.59 \times 10^{4}$ & 1.43 \\
\hline
\end{tabular}

CRL encapsulated in sol-gel material reached up to 6.7 times and 1.43 times that of free enzymes and non-interfacial activated immobilized enzymes, respectively. This was because the hydrophobicity of olive oil was the strongest and the two-phase system was well formed. The lipase lid could effectively open and the esterification activity of vitamin E succinate synthesis by CRL was greatly improved $[8,27,28]$. Compared with previous reports, the esterification activity of vitamin E succinate synthesis by interfacial activated CRL encapsulated in sol-gel materials was obviously improved more than Novozym 435 $[16,17]$.

\section{Conclusions}

The effects of various immobilization conditions on the synthesis of vitamin E succinate by interfacial activated Candida rugosa lipase (CRL) encapsulated in sol-gel materials were investigated. These conditions involved the molar ratio of silane precursors, lipase loading, $R$ value, and amount of PEG400. Optimum conditions were found where $n$-propyltrimethoxysilane $/$ tetraethoxysilane $=1 / 1(\mathrm{~mol} / \mathrm{mol})$, water $/$ silane molar ratio $=20$, lipase loading $=0.5 \mathrm{mg} / \mathrm{ml} \mathrm{sol}$, and PEG400 loading $=12 \mu \mathrm{l} / \mathrm{ml}$ sol, the specific activity was $6279.12 \mathrm{U} / \mathrm{mg}$ protein and the immobilized protein ratio was 95.3\%. The thermal stability and hydrolysis activity were also obviously improved. Lecithin, $n$-OG, olive oil, triacetin, and Tween 20 were used to activate CRL based on the interfacial characteristics of CRL. Compared with non-interfacial activated enzymes, the esterification activities were improved by varying degrees. The results demonstrate that olive oil has the greatest effect on CRL. The esterification activity of vitamin E succinate synthesis by interfacial activated CRL encapsulated in sol-gel materials reached up to 6.7 times and 1.43 times that of free enzymes and non-interfacial activated immobilized enzymes, respectively. Therefore, the sol-gel encapsulating immobilized method and interfacial activation could effectively reform and improve the catalytic ability of the enzyme.

\section{References}

[1] Bornscheuer U T, Huisman G W, Kazlauskas R J, Lutz S, Moore J C, Robins K. Nature, 2012, 485: 185

[2] Hu Y, Liu W M, Zou B, Tang S S, Huang H. Prog Chem (胡炎炎, 刘维明, 邹樹, 唐苏苏, 黄和. 化学进展), 2010, 22: 1656

[3] Reetz M T, Zonta A, Simpelkamp J. Biotechnol Bioeng, 1996, 49: 527

[4] Gill I, Ballesteros A. Trends Biotechnol, 2000, 18: 282

[5] Nguyen D T, Smit M, Dunn B, Zink J I. Chem Mater, 2002, 14: 4300

[6] Noureddini H, Gao X, Joshi S, Wagner P. J Am Oil Chem Soc, 2002, 79: 33

[7] Maruyama T, Nakajima M, Uchikawa S, Nabetani H, Furusaki S, Seki M. J Am Oil Chem Soc, 2000, 77: 1121

[8] Foresti M L, Alimenti G A, Ferreir M L. Enzyme Microb Technol, 2005, 36: 338

[9] Yilmaz E. World J Microbiol Biotechnol, 2002, 18: 37

[10] Prasad K N, Kumar B, Yan X D, Hanson A J, Cole W C. J Am Col Nutrition, 2003, 22: 108

[11] Quin J, Engle D, Litwiller A, Peralta E, Grasch A, Boley T, Hazelrigg 


\title{
Graphical Abstract
}

Chin. J. Catal., 2013, 34: 1608-1616 doi: 10.1016/S1872-2067(12)60628-7

\section{Synthesis of vitamin E succinate by interfacial activated Candida rugosa lipase encapsulated in sol-gel materials}

Yi Hu, Xiangjun Jiang, Suwen Wu, Ling Jiang, He Huang*

Nanjing University of Technology

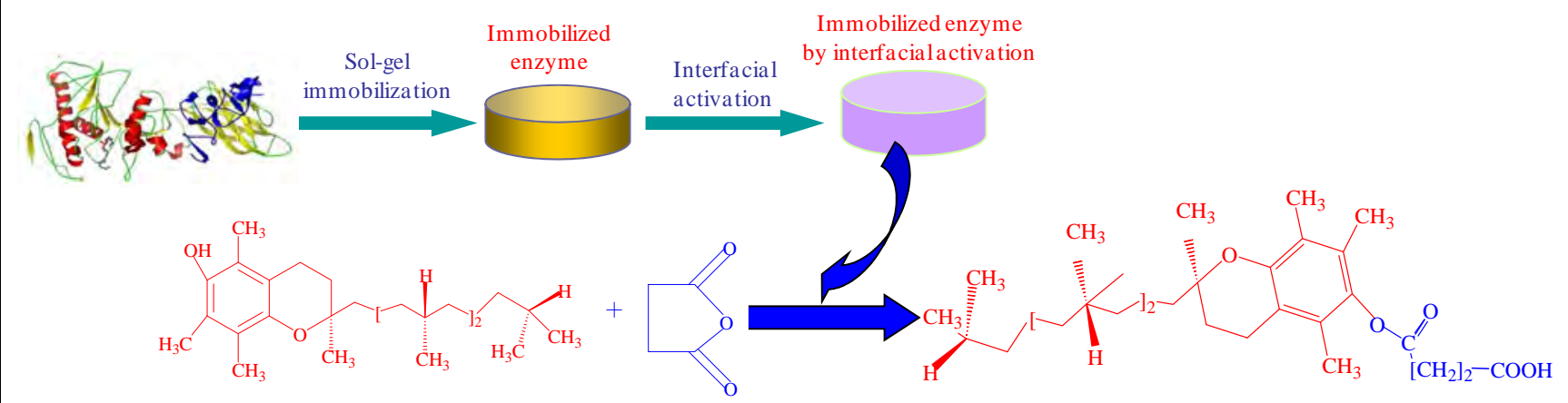

Interfacial activated Candida rugosa lipase encapsulated in sol-gel materials was prepared and used to synthesize vitamin E succinate.

S. J Surgical Res, 2005, 127: 139

[12] Zheng GW, Xu J H. Curr Opin Biotechno, 2011, 22: 784

[13] Kapoor M, Gupta M N. Process Biochem, 2012, 47: 555

[14] Tang S S, Hu Y, Yu D H, Zou B, Jiang L. Chin J Catal (唐苏苏, 胡炏炎, 余 定华, 邹涁, 江凌. 催化学报), 2012, 33: 1473

[15] Ding Y, Huang H, Hu Y. Chin J Org Chem (丁雁, 黄和, 胡炏. 有机化 学), 2013, 33: 905

[16] Torres P, Reyes-Duarte D, López-Cortés N, Ferrer M, Ballesteros A, Plou F J. Process Biochem, 2008, 43: 145

[17] Yin C H, Zhang C, Gao M. Chin J Chem Eng, 2011, 19: 135

[18] Jiang X J, Hu Y, Jiang L, Gong J H, Huang H. Chem Res Chin Univ, 2013, 29: 223

[19] Bradford M M. Anal Biochem, 1976, 72: 248

[20] Cao X W, Yang J K, Shu L, Yu B Q, Yan Y J. Process Biochem, 2009,
44: 177

[21] Chen J P, Lin W S. Enzyme Microb Technol, 2003, 32: 801

[22] Menaa B, Herrero M, Rives V, Lavrenko M, Eggers D K. Biomaterials, 2008, 29: 2710

[23] Yang G, Wu J P, Xu G, Yang L. Bioresour Technol, 2009, 100: 4311

[24] Soares C M F, dos Santos O A, De Castro H F, De Moraes F F, Zanin G M. Appl Biochem Biotechnol, 2004, 113: 307

[25] Gottfried D S, Kagan A, Hoffman B M, Friedman J M. J Phy Chem B, 1999, 103: 2803

[26] Van Tilbeurgh H, Egloff M P, Martinez C, Rugani N, Verger R, Cambillau C. Nature, 1993, 362: 814

[27] Miled N, Bussetta C, De Caro A, Rivière M, Berti L, Canaan S. Comp Biochem Phys B, 2003, 136: 131

[28] Yang J K, Liu LY, Cao X W. Enzyme Microb Technol, 2010, 46: 257

\section{界面活化的溶胶凝胶包埋Candida rugosa脂肪酶催化合成维生素E琥珀酸酯}

\author{
胡 炏竾, 蒋相军 ${ }^{\mathrm{a}}$, 吴素文 ${ }^{\mathrm{a}}$, 江 凌 ${ }^{\mathrm{a}, \mathrm{b}}$, 黄 和 ${ }^{\mathrm{a}, \mathrm{b}, *}$ \\ a南京工业大学生物与制药工程学院, 江苏南京 210009 \\ $\mathrm{b}^{\mathrm{b}}$ 京工业大学材料化学工程国家重点实验室, 江苏南京210009
}

摘要: 采用界面活化的溶胶凝胶包埋Candida rugosa脂肪酶(CRL)催化合成了维生素E琥珀酸酯. 考察了影响溶胶凝胶包埋固定 化CRL的因素, 获得的最佳固定化条件为: 丙基三甲氧基硅烷/正硅酸四乙酯摩尔比为 $1 / 1$, 水与硅烷前体摩尔比为 15 , 酶的添加量 为 $0.5 \mathrm{mg} / \mathrm{ml}$, PEG 400 的添加量为 $12 \mu \mathrm{l} / \mathrm{ml}$ 溶胶. 溶胶凝胶包埋的CRL在 $50^{\circ} \mathrm{C}, 18 \mathrm{~h}$ 后其活性仍然保持了 $70.58 \%$, 是游离酶的 2.6 倍, 且稳定性得到了明显的改善. 基于CRL的界面特性, 采用五种表面活性剂对其进行界面活化. 结果表明, 采用橄榄油活化的溶胶 凝胶包埋的CRL合成维生素E琥珀酸酯的酷化活力最高, 相比原酶和未界面活化的溶胶凝胶包埋酶分别提高了6.7和1.43倍.

关键词: 溶胶凝胶; 界面活化; Candida rugosa脂肪酶; 维生素E琥珀酸酯

收稿日期: 2013-04-22. 接受日期: 2013-05-28. 出版日期: 2013-08-20.

*通讯联系人. 电话/传真: (025)83172094; 电子信箱: biotech@njut.edu.cn

基金来源：国家杰出青年科学基金(21225626); 国家自然科学基金(20906049); 国家高技术研究发展计划(863计划, 2011AA02A209).

本文的英文电子版由Elsevier出版社在ScienceDirect上出版(http://www.sciencedirect.com/science/journal/18722067). 


\section{1. 前言}

固定化酶具有稳定性好、易从反应系统中分离、能 重复使用、便于运输和咜存、有利于生产的连续化和自 动化等优点, 因而具有广阔的应用前景 ${ }^{[1,2]}$. 以有机硅烷 为前体的溶胶凝胶包埋固定化可有效地提高酶的热稳 定性和耐有机溶剂性、酶活回收率高、能维持酶的高级 结构等特点, 成为当前酶固定化重要方法之一 ${ }^{[3,4]}$. Nguyen等 ${ }^{[5]}$ 以硅酸甲酯为前体对肌酸激酶进行溶胶凝 胶包埋固定化, 发现所得固定化酶的热稳定性明显提高, 溶胶凝胶包埋的酶在 $60{ }^{\circ} \mathrm{C}$ 使用 $5 \mathrm{~h}$ 仍能保持 $50 \%$ 的活性， 而游离酶反应 $1 \mathrm{~h}$ 就失去了 $50 \%$ 的活性. Noureddini等 ${ }^{[6]}$ 以异丁基三甲氧基硅烷和硅酸甲酯为前体, 采用溶胶凝 胶包埋脂肪酶 $\mathrm{AY}$. 结果表明, $40 \mathrm{~h}$ 后游离酶在 $40^{\circ} \mathrm{C}$ 以上 会失去大部分活性, 而固定化酶在 $70{ }^{\circ} \mathrm{C}$ 时依然比较稳 定, 重复使用 12 次后依然能保持95\%的活性.

虽然利用溶胶-凝胶包埋固定化法能有效提高酶的 稳定性, 但是经过包埋的酶依然存在催化效率低的问题. 这主要是因为包埋酶的构象并非是形成产物的最佳构 象. 大多数脂肪酶都有一个 “盖子” 结构, 只有当该盖子 结构打开之后, 底物才能进入其催化活性中心完成催化 过程. Maruyama等 ${ }^{[7]}$ 已经证明, 大多数脂肪酶在水相中 盖子结构处于关闭状态, 而在油水的两相界面中常常处 于打开的状态. 而在有机溶剂中, 由于缺少这种“界面激 活”作用, 脂肪酶的盖子结构通常是关闭的, 这是导致脂 肪酶在有机溶剂中催化效率低的重要因素之一. 如果能 够在催化前预先打开脂肪酶的盖子结构, 那么就能有效 提高脂肪酶的催化效率. 脂肪酶的盖子结构可在油水两 相体系中通过界面活化作用来打开. Foresti等 ${ }^{[8]}$ 采用油 水界面活化的聚丙烯固定的 Candida rugosa脂肪酶 (CRL) 在无溶剂体系中催化油酸和乙醇合成油酸乙酯, 相比未界面活化的固定化酶, 其酯化活力提升了 $29 \%$. Yilmaz ${ }^{[9]}$ 利用卵磷脂、吐温20、橄榄油等表面活性剂对 猪胰脂肪酶和Pseudomonas fluorescens脂肪酶进行界面 活化, 在正己烷中催化辛酸乙酯和三油酸甘油酯进行酯 交换反应,研究表明利用卵磷脂活化的猪胰脂肪酶和 Pseudomonas fluorescens脂肪酶酯交换活力都升高了 4 倍左右.

维生素E琥珀酸酯是一种重要的维生素E衍生物, 除 具有维生素 $\mathrm{E}$ 的功能外, 对各类肿瘤及恶性肿瘤均有显 著的作用, 且不影响正常细胞的增殖, 是一种潜在的抗 癌药物 ${ }^{[10,11]}$. 随着近年来人们对绿色合成工艺的重视,
利用生物催化剂来代替传统的化学催化剂已成为当前 研究的热点 ${ }^{[12,13]}$. 生物催化剂在 Michael 加成、 Markovnikov加成及羟醛缩合等多种催化反应中有着重 要的应用 ${ }^{[14,15]}$. Torres 等 ${ }^{[16]}$ 首次报道了利用 Novozym 435在叔戊醇中催化合成维生素 $\mathrm{E}$ 的酯化反应, 反应 $18 \mathrm{~d}$ 后底物转化率仅为 $65 \%$. Yin等 ${ }^{[17]}$ 在叔戊醇和DMSO的 混合溶液 $(\mathrm{v} / \mathrm{v}=2: 3)$ 中进行酸䣶修饰的Novozym 435催 化合成维生素 $\mathrm{E}$ 虎珀酸酯实验, 反应 $18 \mathrm{~h}$ 后底物转化率 为 $94.4 \%$, 然而未修饰的Novozym 435仅为 $13.13 \%$. 本课 题组研究了影响合成维生素E琥珀酸酯(图式1)的脂肪酶 种类、有机溶剂种类与工艺条件 ${ }^{[18]}$, 为进一步提高维生 素 $\mathrm{E}$ 琥珀酸酯合成效率, 本文拟通过溶胶凝胶包埋固定 化和界面活化的方法对CRL进行改造, 以提高原酶的酯 化活力.

\section{2. 实验部分}

\section{1. 溶胶凝胶固定化CRL的制备}

将一定质量的CRL (购自 Sigma-Aldrich公司)溶解到 磷酸缓冲溶液中 $(0.025 \mathrm{~mol} / \mathrm{L}, \mathrm{pH}=7.0)$ ), 离心(转速 6000 $\left.\mathrm{r} / \mathrm{min}, 4^{\circ} \mathrm{C}, 10 \mathrm{~min}\right)$, 取上清液备用. 按一定摩尔比的丙 基三甲氧硅烷(PTMS, 97\%, Aladdin-reagent)和正硅酸四 乙酯 (TEOS, AR, Aladdin-reagent) $12 \mathrm{mmol}$ 高速摚拌混 合均匀, 依次加入 $1.5 \mathrm{ml}$ 去离子水、盐酸 $(1 \mathrm{~mol} / \mathrm{L}, 90 \mu \mathrm{l})$ 和一定量的聚乙二醇400 (PEG400)搅拌30 min后得到均 匀的硅烷前体. 将上清液加入到硅烷前体中, 摚拌 10 $\min$ 后转为低速继续摚拌 $1 \mathrm{~h}$, 再放入 $4^{\circ} \mathrm{C}$ 陈化 $24 \mathrm{~h}$. 陈化 结束后, 在 $30^{\circ} \mathrm{C}$ 下真空干燥 $3 \mathrm{~d}$, 待产物干燥后磨成颗粒 即为固定化酶.

\section{2. 界面活化的溶胶凝胶固定化CRL的制备}

取一定量的 CRL 加入到磷酸缓冲液 $(0.025 \mathrm{~mol} / \mathrm{L}$, $\mathrm{pH}=7.0)$ 中, 然后离心 $\left(6000 \mathrm{r} / \mathrm{min}, 4^{\circ} \mathrm{C}, 10 \mathrm{~min}\right)$, 取上清 分别加入一定量的橄榄油、三乙酸甘油酯、吐温20、卵 磷脂和 $n-O G$, 搅拌 $30 \mathrm{~min}$, 而后对其进行溶胶凝胶固定 化(固定化过程如2.1节). 界面活化的溶胶凝胶固定化 CRL经干燥和磨成颗粒后, 用苯/乙醇( $(90 / 10, v / v)$ 冲洗去 $n$-OG和吐温20, 用正己烷冲洗去除橄榄油、三乙酸甘油 酯和卵磷脂. 自然晾干得界面活化的溶胶-凝胶固定化 酶.

\section{3. 固定化效率的测定}

将干燥后的凝胶固体取出后, 用磷酸盐缓冲液多次 清洗并收集洗涤液. 按照Bradford的方法, 以牛血清蛋 白作为标准蛋白质绘制标准曲线 ${ }^{[19]}$. 测定固定化后残 
液的吸光值, 根据标准曲线计算蛋白浓度. 根据下式计 算固定化效率 $\mathrm{IY}=\left(C_{\mathrm{i}}-C_{\mathrm{f}}\right) / C_{\mathrm{i}} \times 100 \%$. 其中, $C_{\mathrm{i}}$ 表示溶液 中固定化前酶蛋白的初始浓度 $(\mathrm{mg} / \mathrm{ml}) ; C_{\mathrm{f}}$ 表示固定化 过程中未被结合的酶蛋白的最终浓度 $(\mathrm{mg} / \mathrm{ml})$.

\section{4. 比表面积和孔径大小的测定}

样品的 $\mathrm{N}_{2}$ 吸附 - 脱附曲线在 Micromeritics ASAP 2020 型自动吸附仪上测定. 实验前于 $80^{\circ} \mathrm{C}$ 脱气 $12 \mathrm{~h}$, 比 表面积采用BET法计算, 孔径大小由BJH方法算得 ${ }^{[18]}$.

\section{5. 水解活性测定}

酶水解活性采用橄榄油水解法测定. 将 $8.5 \mathrm{~g}$ 阿拉伯 树胶粉, $100 \mathrm{ml}$ 去离子水和 $100 \mathrm{ml}$ 橄榄油混合后于室温 高速过夜摚拌得到橄榄油乳化液. 分别取 $10 \mathrm{ml}$ 橄榄油 乳化液和 $10 \mathrm{ml}(\mathrm{pH}=7.0,0.025 \mathrm{~mol} / \mathrm{L})$ 磷酸缓冲溶液于 $50 \mathrm{ml}$ 烧杯中混匀, 加入一定量的酶, 在保持 $\mathrm{pH} 7.0$, 反应 温度为 $35^{\circ} \mathrm{C}$, 反应过程产生的酸在电位滴定仪上采用 $0.025 \mathrm{~mol} / \mathrm{L}$ 的 $\mathrm{NaOH}$ 连续滴定, 并记录 $10 \mathrm{~min}$ 内消耗 $\mathrm{NaOH}$ 溶液的体积. 酶活单位 $(\mathrm{U})$ 的定义为每分钟催化橄 榄油生成 $1 \mu \mathrm{mol}$ 脂肪酸所需的酶量. 比活力 $(\mathrm{U} / \mathrm{g})=$ 固 定化CRL的表观活力 $(\mathrm{U}) /$ 固定化酶中 CRL 的蛋白含量 (g).

\section{6. 热稳定性的考察}

将一定量的游离酶或固定化酶加入到一定体积的 磷酸盐 $(\mathrm{pH}=7.0,0.025 \mathrm{~mol} / \mathrm{L})$ 缓冲液中, 并置于 30-60 ${ }^{\circ} \mathrm{C}$ 水浴锅中保温 $18 \mathrm{~h}$, 然后取出, 冷却后加入到橄榄油体 系中, 按照 2.5 节的方法测定水解活力.

\section{7. 酯化活性考察}

取1 mmol维生素E (AR, 购自 Sigma-Aldrich公司), 5 $\mathrm{mmol}$ 丁二酸䣶(AR, 国药集团化学试剂有限公司)和一 定质量的原酶、溶胶凝胶固定化酶或者界面活化的溶胶 凝胶固定化酶加入到含有 $5 \mathrm{ml}$ DMSO的 $25 \mathrm{ml}$ 具塞雉形 瓶中, 在 $55^{\circ} \mathrm{C}$ 恒温水浴振荡器中反应 $18 \mathrm{~h}$ (转速为 100 $\mathrm{r} / \mathrm{min}$ ). 反应结束后采用配有 SPD-20AVP UV-Vis检测 器的岛津HPLC进行分析, 色谱柱(Sepax BR-C18, 250 $\mathrm{mm} \times 4 \mathrm{~mm}, 5 \mu \mathrm{m})$, 温度 $36{ }^{\circ} \mathrm{C}$, 流动相甲醇 $/ 乙$ 酸 $(50 / 0.3$, $\mathrm{v} / \mathrm{v})$, 检测波长 $285 \mathrm{~nm}$, 流速 $1 \mathrm{ml} / \mathrm{min}$. 酯化活力定义为 每克酶蛋白每小时催化底物(维生素E)转化为 $1 \mu \mathrm{mol}$ 产 物维生素E琥珀酸酯的量 $(\mu \mathrm{mol} /(\mathrm{h} \cdot \mathrm{g}))$

\section{3. 结果与讨论}

\section{1. 固定化条件对固定化CRL的影响}

\subsection{1. 硅烷前体比例的影响}

疏水性和亲水性的硅烷前体的比例将决定凝胶材
料的疏水性. 当该比例较高时, 由于凝胶的疏水性较强, 其在聚合中容易使水“挤出”, 造成凝胶相与水相分离. 因此, 只有当两相的分离速度与凝胶聚合的速度达到平 衡时, 酶分子才能被包住 ${ }^{[20]}$. 由于脂肪酶是一种界面酶, 适宜的表面疏水性将有利于酶分子维持有利的催化构 型 ${ }^{[3]}$. 所以, 疏水性和亲水性硅烷前体的比值存在最佳 值. 因此, 首先考察了疏水性的PTMS和亲水性的TEOS 的比例对固定化酶的比活和蛋白负载量的影响, 结果见 图1. 可以看出, 随着混合物中前体PTMS含量的降低, 蛋白结合率下降; 固定化酶的比活力先升后降, 在 $1: 1$ 时 达到最大值. 因此, 确定将硅烷前体的比例 $1: 1$ 作为后续 固定化的最佳条件.

\subsection{2. 酶添加量的影响}

酶的添加量将直接影响固定化载体的负载量, 也会 间接对固定化酶的比活产生重要的影响. 酶的负载量较 低时, 酶分子容易受到凝胶载体的强疏水性作用而使其 有利的构象发生扭曲. 因此, 随着酶负载量的增加, 酶的 比活会升高 ${ }^{[21]}$. 而酶添加量较高则容易导致酶的聚集 以及扩散限制等效应, 降低酶的催化效率. 图2考察了当 PTMS/TEOS为 $1: 1$, 水和硅烷的摩尔比 ( $R$ 值)为 20, PEG 的量为 $80 \mu \mathrm{l} / \mathrm{ml}$ 时不同的酶添加量对固定化的影响. 由 图可见, 当酶的添加量小于 $0.5 \mathrm{mg} / \mathrm{ml}$ 时, 随着酶浓度的 增加, 固定化酶的比活以及固定蛋白量都在增加. 当酶 的添加量大于 $0.5 \mathrm{mg} / \mathrm{ml}$ 时, 酶的比活和固定化效率均在 降低. 即当酶的添加量为 $0.5 \mathrm{mg} / \mathrm{ml}$ 时固定化酶的酶活 和固定化效率最佳.

\subsection{3. 水添加量的影响}

在溶胶凝胶制备过程中通常采用 $R$ 值来表示添加水 和硅烷前体摩尔比值. 如图3所示, 当 $R$ 值 $<15$ 时, 酶活和 固定化效率都较低; 当 $R$ 值 $>15$ 时, 固定化酶的活性和固 定化效率下降; 而在 $R=15$ 时, 固定化酶的比活和蛋白 负载量都达到最大. 这可能是由于当 $R$ 值较低时, 酶分 子容易发生聚集, 造成催化效率降低. 同时, 由于前体水 解和聚合过程中产生乙醇, 低的水添加量将导致乙醇浓 度过高, 对酶蛋白不利. 然而当 $R$ 值较高时, 酶分子则容 易留在水相中, 使得酶蛋白的结合效率下降 ${ }^{[22]}$.

\subsubsection{PEG400的添加量的影响}

PEG400可先于酶吸附在凝胶表面, 从而减弱酶与 凝胶间相互作用, 而且PEG400具有良好的生物相容性, 能较好地保持酶的活性. 此外, PEG400的添加量对凝胶 网的结构也有较大的影响 ${ }^{[23,24]}$.

如图4所示, 随着PEG400量的增加, 包埋酶的比活 
先升高, $12 \mu \mathrm{l} / \mathrm{ml}$ 时达最大值为 $6279.12 \mathrm{U} / \mathrm{mg}$, 比游离酶 的 $1732.8 \mathrm{U} / \mathrm{mg}$ 提高了 3.6 倍, 而此时蛋白固定化效率达 到了 95.3\%. 综上所述, 固定化的最佳条件为硅烷前体 摩尔比为 $1: 1$, 酶添加量 $0.5 \mathrm{mg} / \mathrm{ml}, R=15$, PEG400的添 加量 $12 \mu \mathrm{l} / \mathrm{ml}$.

\subsection{5. 溶胶凝胶的比表面积和孔径}

表1为比表面积和孔径大小. 可以看出,包埋酶的溶 胶凝胶颗粒的比表面积大于未包埋酶的溶胶凝胶的表 面积大, 而孔径相对较小. 这是由于在凝胶形成的过程 中大分子的酶分子被包埋在其中, 形成的凝胶结构比未 包埋酶的疏松多孔, 因而比表面积大. 另一方面, 由于酶 被包埋在孔道中, 其孔径相对未包被酶的凝胶来说会小, 这些变化说明了CRL成功地被包埋在凝胶中. 此外, 固 定化酶的比表面积比空白的大, 有利于底物和产物出入 酶的催化活性中心, 使得酶的催化效率较高 ${ }^{[25,26]}$.

\section{2. 酶学性质考察}

\subsection{1. 热稳定性}

热稳定性是酶非常重要的一种性质, Nguyen等 ${ }^{[5]}$ 发 现, 利用溶胶凝胶包埋可有效提高酶的热稳定. 图5考察 了在上述最佳固定化条件下制备的固定化酶的热稳定 性. 可以看出, 经过固定化后, 脂肪酶的稳定性明显改 善. 特别在 50 和 $60^{\circ} \mathrm{C}$ 时, 固定化酶分别能保持 $70.58 \%$ 和 $68.11 \%$ 的酶活，而游离酶的酶活仅保持 $26.72 \%$ 和 $12.68 \%$. 溶胶凝胶包埋酶稳定性得到提高的原因可能 在于酶分子被包被在刚性的聚合物里, 其运动(如折叠 和旋转)受到限制 ${ }^{[24]}$.

\subsection{2. 不同表面活性剂界面活化的CRL酯化活力比较}

与其它酯酶不同, 脂肪酶的催化过程是在油-水界 面间完成，因此表现出特有的界面活性 (interfacial activation). 这是由脂肪酶独特的盖子结构决定的, 脂肪
酶结构晶体学的研究表明, 脂肪酶的活性位点上有一个 螺旋型的盖子, 它的存在使酶的活性中心与分子表面被 隔开, 盖子下面覆盖的是由疏水基包围的、由亲水基组 成的脂肪酶亲电区 (也称作氧负离子洞 $)^{[25,26]}$. 在由表面 活性剂和水形成的两相界面中, 脂肪酶的盖子结构会被 打开, 催化活性中心就暴露出来, 这样就很容易与底物 相结合. 如表2所示, 相比游离酶和未界面活化的溶胶凝 胶固定化酶, 经表面活性剂界面活化的酶酯化活力均有 所增加, 其中效果最好的表面活性剂为橄榄油, 对应的 酯化活力是未界面活化的溶胶凝胶酶的 1.43 倍, 高达 $7.59 \times 10^{4} \mathrm{U}$; 是原酶 $\left(1.13 \times 10^{4} \mathrm{U}\right)$ 的6.7倍. 这可能是由于 在所选择的表面活性剂中以橄榄油的疏水性最强, 形成 的两相体系效果最好, 能有效打开脂肪酶的盖子结构, 因而明显地提高了CRL合成维生素E琥珀酸酯的反应活 性 ${ }^{[8,27,28]}$, 其酯化活性明显高于Novozym $435^{[16,17]}$.

\section{4. 结论}

对影响溶胶-凝胶包埋固定化的硅烷前体的比例, 酶、水和PEG400的添加量等因素进行了考察, 获得的最 佳固定化条件为: 硅烷前体的摩尔比为 $1: 1$, 酶的添加量 为 $0.5 \mathrm{mg} / \mathrm{ml}, R=15$, PEG400 的添加量为 $12 \mu \mathrm{l} / \mathrm{ml}$, 固定 化效率为 $95.3 \%$, 水解活力为 $6279.12 \mathrm{U} / \mathrm{mg}$. 相比游离的 CRL, 其热稳定性和水解活性明显提高. 利用橄榄油、三 乙酸甘油酯、吐温20、卵磷脂和 $n-O G$ 等表面活性剂对溶 胶凝胶包埋的CRL进行界面活化, 发现其酯化活力明显 高于原酶和未界面活化的溶胶凝胶固定化酶, 其中以橄 榄油活化效果最为明显, 催化合成维生素E琥珀酸酯的 酯化活力提升到原来的1.43倍, 是原酶的6.7倍. 因此, 利 用溶胶-凝胶包埋法和界面活化能有效地对酶进行改造, 并定向改善酶的催化合成能力. 